\title{
THE INFLUENCE OF STRATEGIC HRM IMPLEMENTATION ON INNOVATION PERFORMANCE WITH THE KNOWLEDGE MANAGEMENT CAPACITY AS A MEDIATOR IN PUBLIC HOSPITAL ZAINOEL ABIDIN
}

\author{
*M. Zubir, Syafruddin, Iskandarsyah \\ Management Department, Universitas Syiah Kuala, Indonesia \\ http://doi.org/10.35409/IJBMER.2020.3192
}

\begin{abstract}
Innovation is an important for the progress of society because it solves these social problems and increases the capacity of the community to act. It is responsible for solving collective problems in a sustainable and efficient way, usually with new technology. The purpose of this study is to look at the effects of Strategic HRM (human resource management) and knowledge management on innovation performance. This research was conducted at Zainoel Abidin Regional Public Hospital (RSUZDA) in Banda Aceh City with the research population is all its employees, both medical and non-paramedical employees, totaling 2,495 people. The sample was selected using purposive sampling technique, and determined as representative as much as 155 respondents. The results showed that of the 3 direct hypotheses were all accepted because they had CR and P values that met the test requirements. The results of indirect hypothesis testing namely the Effect of Strategic HRM on Innovation Performance through knowledge management was also significant. The significance of direct and indirect effects concluded that the role of knowledge management variables in this case acted as partial mediators. In addition, Strategic HRM was proven to have the greatest contribution to improve Innovation Performance at the Zainoel Abidin Regional Public Hospital in Banda Aceh. All of these findings in the tested model can contribute to the field of science, especially in the field of management. Updating the theory of causality is the research novelty and this also makes it a reference for practitioners, especially for the leaders or managers in Zainoel Abidin Regional Public Hospital to reorganize their organizational strategies and policies.
\end{abstract}

Keyword: Strategic HRM, Knowledge Management, Innovation Performance.

\section{INTRODUCTION}

Over the past few decades, innovation has become a significant way to combat critical social risks and threats. Innovation is important for the progress of society because it solves these social problems and increases the capacity of the community to act. It is responsible for solving collective problems in a sustainable and efficient way, usually with new technology. These new technologies, products and services simultaneously meet social needs and lead to increased capacity and better use of assets and resources.

In the context of innovation companies also continue to be encouraged to grow. Because 


\section{International Journal of Business Management and Economic Review}

Vol. 3, No. 04; 2020

ISSN: 2581-4664

innovation is a distinguishing factor that leads to differentiation that will become one of the company's competitive advantages.

For innovation to occur, companies can utilize human capital to develop organizational expertise in order to create new products and services. However, skills are complex and are the result of deliberate practice in the domain of representative tasks (Oke, Walumbwa and Myers, 2012). HR (Human Resource) practice like this requires individuals who have high motivation in carrying out tasks and make efforts to improve performance.

In addition to Strategic HRM (Human Resource Management) factors, knowledge management sharing factors are also a decisive factor in supporting the performance of corporate innovation. According to (Hu, Horng and Sun, 2009) the management of knowledge sharing and team culture has been found to have an important influence on service innovation performance (Service Innovation Performance).

In the context of hospitals, because they have become a health industry, hospitals are also faced with competition, both with fellow state hospitals such as the Zainoel Abidin Regional Public Hospital (RSUDZA) with the Meuraxa Public Hospital (RSUDM) or with private public hospitals many of which are here in Banda Aceh.

\section{LITERATURE REVIEW}

\section{Strategic HRM (Human Resource Management)}

As a valuable resource, HR has differences because of the diverse demands of work that require diverse skills, knowledge and behavior. The difference in the contribution of HR in the organization also means having different values according to their respective levels. Maturity in the ability of high quality and ability of workers is related to the level of skills and competencies.

Strategic HRM leads the broad organizational issues relating to changes in the structure and culture, organizational effectiveness and also performance, resources that are suitable for future needs, development of Human Resource (HR) distinctive capabilities, knowledge management, and also change management. Strategic HRM is defined as organizational orientation and plans for how business goals should be achieved through people (Chen and Indartono, 2011). This is based on three propositions: first, that human capital is the main source of competitive advantage; second, that those who carry out strategic plans; and, third, that a systematic approach must be used to define the direction and goals of the organization to be achieved (Cardeal and Antonio, 2012).

The perspective of (Collins and Clark, 2003) stated that Strategic HR management must unite, harmonize and integrate broader needs. According to (Sherafati, Mohammadi and Bidabad, 2014), Strategic HR management places more emphasis on human relations aspects of people management, emphasizing in the sustainable development, communication, involvement, job security, quality of work life and work life balance and ethical balance.

\section{Knowledge Management}

(Randeree, 2006) stated that the knowledge management plays an increasingly strategic and important role in many organizations and business, because he realized that competitiveness depends on effective intellectual resource management. In line with (Randeree, 2006), (Palacios, Gil and Garrigos, 2009) described that the knowledge management is as a management system 


\section{International Journal of Business Management and Economic Review}

Vol. 3, No. 04; 2020

ISSN: 2581-4664

that captures the aspects of an established model of the organization and extends it to provide a practical methodology. They defined the content of knowledge management which consists of two dimensions: principles and practice. Their specific concept stated that the knowledge management is a management tool that is characterized by a set of principles along with the series of practices and also techniques through the principles introduced, the purpose being to create, change, disseminate and utilize knowledge (Azhari, Musnadi and Tabrani, 2017).

Adoption of knowledge management has proven the positive impact on organizational processes that create, store, distribute and interpret knowledge as well as the recruitment, retention and active involvement of talented employees. Knowledge management also has a positive impact on a company's ability to manage research and development projects in order to elevate internal capabilities for the introduction of knowledge and to increase the stock of knowledge that is available (Gloet and Terziovski, 2004).

\section{Innovation Performance}

The theory underlying this concept of performance was originally put forward by (Bernardin and Russell, 2012), stated that: "Performance is figured as the record of outcomes produced on a specified job function or activity during a specified time period". This output or outcome record is very required by the company to measure the extent of the work results of each employee (Rizqina, Adam and Chan, 2017). According to (Shahnaei and Long, 2015), the easiest way to detect the success of innovation is through checking for new customers (customer acquisition), sales growth, customer loyalty, and increasing profit margins.

Innovation performance is measured by the Innovation Metrics. The Innovation Metric consists of a set of tools and systems to measure the innovation performance of an organization (Bes and Kotler, 2011). These metrics can be grouped into four categories, namely metrics that measure the results of innovation from an economic perspective, metrics that measure the intensity of innovation in a department or business unit or organization, metrics that measure the effectiveness of innovative activities and investments, and metrics that measure the extent of creative culture in an organization (Fachreza, Musnadi and Shabri, 2018).

\section{Research paradigm}

The paradigm or relationship between variables in this study can be illustrated in Figure 1 below.

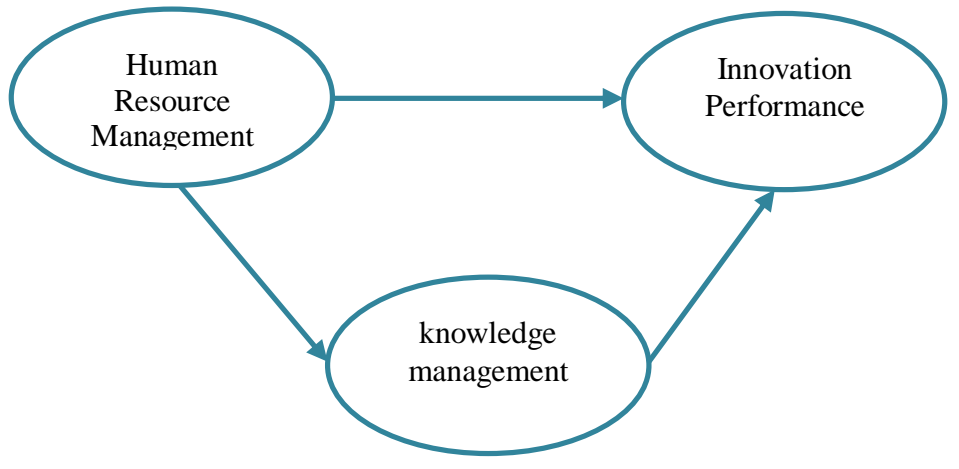




\section{International Journal of Business Management and Economic Review}

Vol. 3, No. 04; 2020

ISSN: 2581-4664

Figure 1 Research Paradigm

\section{Hypothesis}

Based on the theoretical framework previously stated, the hypothesis of this study can be formulated as follows:

H1: Implementation of Strategic HRM influences Performance Innovation at the Zainoel Abidin Regional Public Hospital in Banda Aceh.

H2: Implementation of Strategic HRM influences Knowledge Management capacity at the Zainoel Abidin Regional Public Hospital in Banda Aceh.

H3: Knowledge Management capacity influences Performance Innovation at the Zainoel Abidin Regional Public Hospital in Banda Aceh.

H4: Knowledge Management capacity mediates the relationship between the implementation of Strategic HRM on Performance Innovation at the Zainoel Abidin Regional Public Hospital in Banda Aceh.

\section{RESEARCH METHOD}

\section{Location and Research Object}

This research was conducted at Zainoel Abidin Regional Public Hospital (RSUDZA) located in Banda Aceh City. The research variables are the Strategic HRM, Innovation Performance and Knowledge Management Capacity.

\section{Sampling}

The population in this study was all employees at the Zainoel Abidin Regional Public Hospital in Banda Aceh, both medical and non-paramedical employees, totaling 2,495 people. The sample was selected using purposive sampling with the consideration that the position holder has the task, authority, control and greater involvement in carrying out the administrative structure, planning and budgeting at the Hospital. The criteria used were those who related to the service function in the hospital, both directly such as paramedics, security personnel or those who indirectly related, but what they work has an impact on the quality of service at Zainoel Abidin Regional Public Hospital.

The number of representative samples for a study is the number of indicators multiplied by 5 (Ferdinand, 2014). Because the number of indicators in this study is 31, the respondents sampled should be 155 people. So there were 155 respondents who met the criteria become this research sample.

\section{Data analysis method}

Data processing obtained in the field is done by the equation model technique, which is a multivariate statistical analysis technique to be able to analyze not only the influence between variables, but also the relationship of variables with their respective indicators. The criteria for accepting Ha are Critical Ratio (CR) 1.96 and Probability value $(\mathrm{P})<0.05$. 
International Journal of Business Management and Economic Review

Vol. 3, No. 04; 2020

ISSN: 2581-4664

\section{RESULT AND DISCUSSION}

\section{Loading Factor with measurement test}

Testing the validity of the loading factor can be seen in the following figure and table:

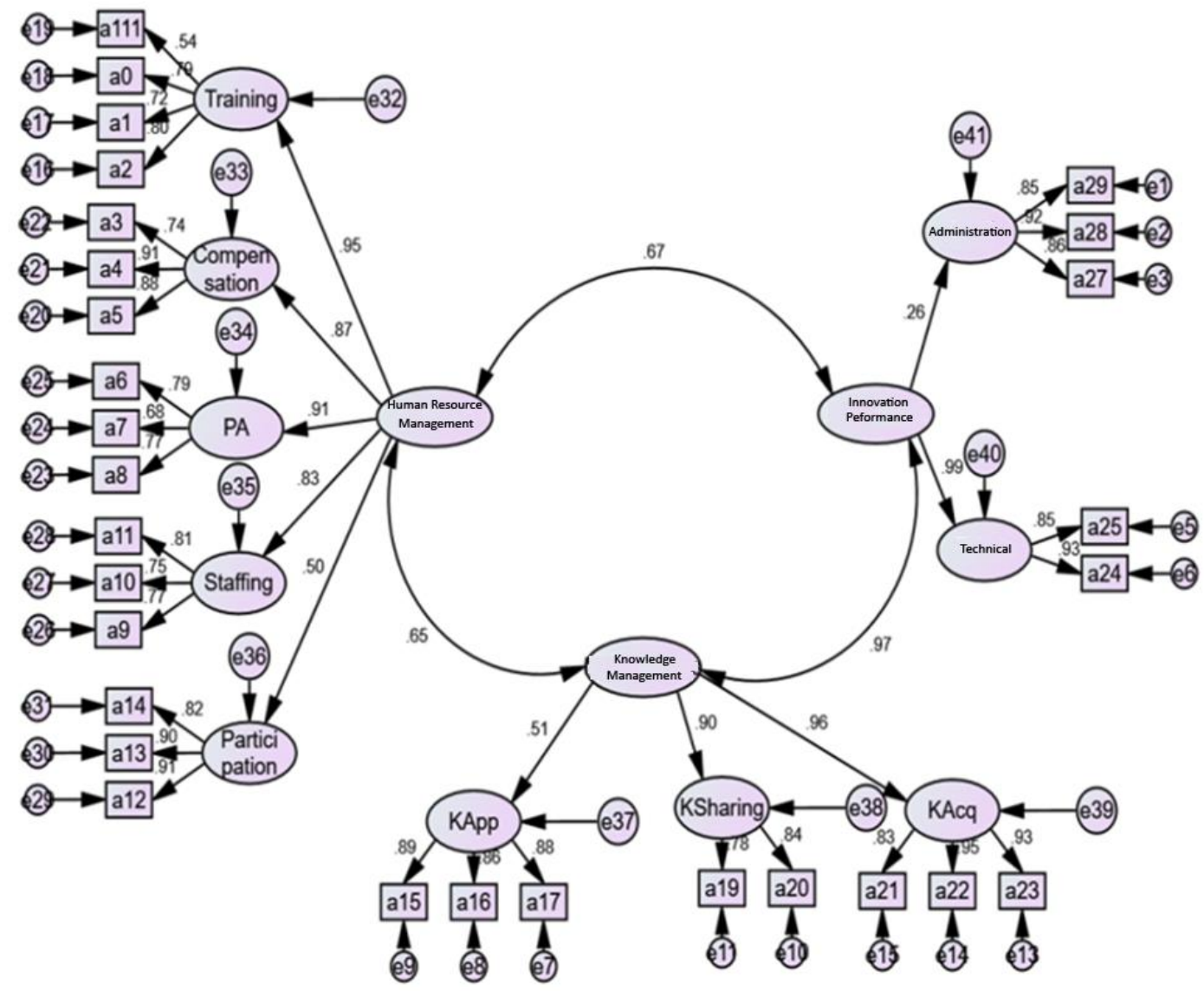

Figure 2 Loading Factor

Measurement test results indicate that several indicators of the research variable have a loading factor value below 0.5. The following table is the result of a net measurement test which can later be included in structural testing. 
International Journal of Business Management and Economic Review

Vol. 3, No. 04; 2020

ISSN: 2581-4664

\section{Table 1. Loading Factor}

\begin{tabular}{|l|l|l|l|l|}
\hline No & Indicator & & Variable & Estimate \\
\hline 1 & Training & K--- & HRM & .954 \\
\hline 2 & Compen_sation & $<---$ & HRM & .872 \\
\hline 3 & PA & $<---$ & HRM & .908 \\
\hline 4 & Staffing & $<---$ & HRM & .832 \\
\hline 5 & Partici_pation & $<---$ & HRM & .497 \\
\hline 6 & KApp & $<---$ & MKnowledge & .511 \\
\hline 7 & KSharing & $<---$ & MKnowledge & .900 \\
\hline 8 & KAcq & $<---$ & MKnowledge & .965 \\
\hline 9 & Adm & $<---$ & KinInovasi & 259 \\
\hline 10 & Technical & $<---$ & KinInovasi & .985 \\
\hline 11 & a29 & $<---$ & Adm & .846 \\
\hline 12 & a28 & $<---$ & Adm & .922 \\
\hline 13 & a27 & $<---$ & Adm & .858 \\
\hline 14 & a25 & $<---$ & Technical & 853 \\
\hline 15 & a24 & $<---$ & Technical & .933 \\
\hline 16 & a17 & $<---$ & KApp & .877 \\
\hline 17 & a16 & $<---$ & KApp & .857 \\
\hline 18 & a15 & $<---$ & KApp & .895 \\
\hline 19 & a20 & $<---$ & KSharing & .841 \\
\hline 20 & a19 & $<---$ & KSharing & .775 \\
\hline 21 & a23 & $<---$ & KAcq & .927 \\
\hline 22 & a22 & $<---$ & KAcq & .945 \\
\hline 23 & a21 & $<---$ & KAcq & .830 \\
\hline 24 & a2 & $<---$ & Training & .797 \\
\hline 25 & a1 & $<---$ & Training & .724 \\
\hline 26 & a0 & $<---$ & Training & .788 \\
\hline 27 & a111 & $<---$ & Training & .541 \\
\hline 28 & a5 & $<---$ & Compen_sation & .878 \\
\hline 29 & a4 & $<---$ & Compen_sation & .906 \\
\hline 30 & a3 & $<---$ & Compen_sation & .743 \\
\hline 31 & a8 & $<---$ & PA & .766 \\
\hline 32 & a7 & $<---$ & PA & 678 \\
\hline 33 & a6 & $<---$ & PA & .787 \\
\hline 34 & a9 & $<---$ & Staffing & .769 \\
\hline 35 & a10 & $<---$ & Staffing & .751 \\
\hline 36 & a11 & $<---$ & Staffing & .810 \\
\hline & & & \\
\hline
\end{tabular}


International Journal of Business Management and Economic Review

Vol. 3, No. 04; 2020

ISSN: 2581-4664

\begin{tabular}{|l|l|l|l|l|}
\hline \hline No & Indicator & & Variable & Estimate \\
\hline 37 & a12 & K--- & Partici_pation & .913 \\
\hline 38 & a13 & K--- & Partici_pation & .896 \\
\hline 39 & a14 & K--- & Partici_pation & .821 \\
\hline
\end{tabular}

Table 1 figures the loading factors of all the indicators in the model, and are eligible for further processing because they have a loading factor $>0.5$.

Table 2. Goodness of Fit

\begin{tabular}{|l|l|l|l|}
\hline Size Index Criteria & Cut-off Value & Result Analysis & $\begin{array}{l}\text { Evaluation of the } \\
\text { Model }\end{array}$ \\
\hline Chi Square & $\begin{array}{l}\text { Expected to be } \\
\text { small }\end{array}$ & 700.262 & Fit \\
\hline CMIN / DF & CMIN / DF $<2$ & 1.945 & Fit \\
\hline GFI & $\geq 0.90$ & 0.906 & Fit \\
\hline AGFI & $\geq 0.90$ & 0871 & Well \\
\hline IFI & $\geq 0.90$ & 0907 & Well \\
\hline CFI & Approaching 1 & CFI above 0.5 & Relatively Good \\
\hline PNFI & $0-1$ & PNFI 0 - 1 & Fit \\
\hline RMSEA & $<0.08$ & 0.057 & Fit \\
\hline
\end{tabular}

\section{Structural Analysis for Direct Hypothesis}

The results of structural tests carried out have produced the information needed to answer hypotheses that have been built before whether proven or not. Figure 3 below illustrates the influence between variables: 
Vol. 3, No. 04; 2020

ISSN: 2581-4664

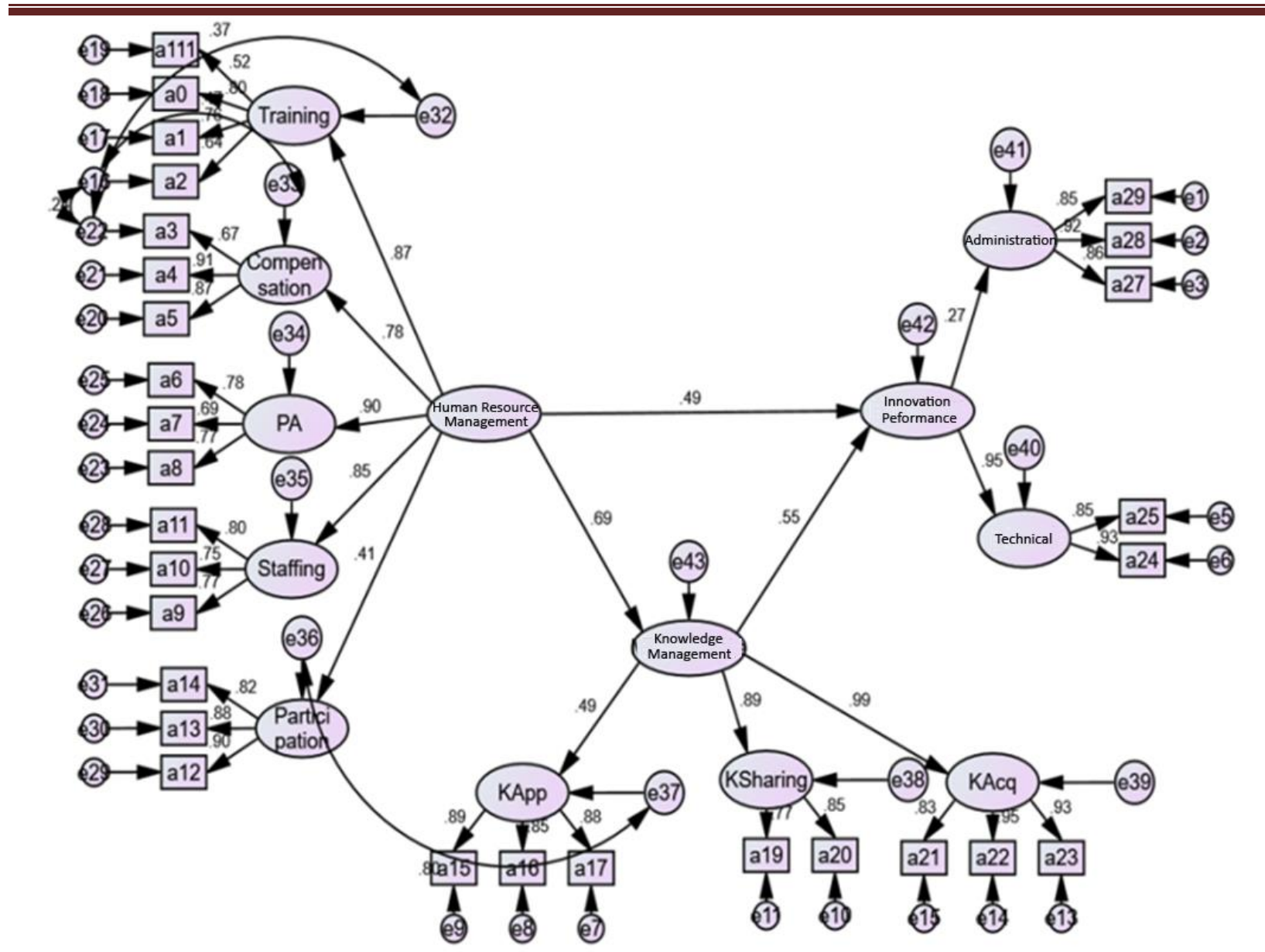

Figure 3. Structural Equation Model

Figure 3 explains the effect coefficient among variables of Strategic HRM, Knowledge Management and innovation performance.

An overview of all hypotheses testing together with the results can be seen in the following Table 3:

Table 3. Direct Hypothesis Test Result

\begin{tabular}{|l|l|l|l|l|}
\hline No & Hypothesis & $\begin{array}{l}\text { CR Cut off }> \\
\mathbf{1 . 9 6}\end{array}$ & $\begin{array}{l}\text { P value } \\
\text { Cut off }<\mathbf{0 . 0 5}\end{array}$ & $\begin{array}{l}\text { Informati } \\
\text { on }\end{array}$ \\
\hline 1 & $\begin{array}{l}\text { The Influence of Strategic HRM on } \\
\text { Knowledge Management }\end{array}$ & 8.347 & $* * *$ & 688 \\
\hline 2 & $\begin{array}{l}\text { The Influence of Strategic HRM on } \\
\text { Innovation Performance }\end{array}$ & 14.625 & $* * *$ & .487 \\
\hline 3 & $\begin{array}{l}\text { The influence of knowledge } \\
\text { management on innovation }\end{array}$ & 14.627 & $* * *$ & .550 \\
\hline
\end{tabular}


Vol. 3, No. 04; 2020

ISSN: 2581-4664

\begin{tabular}{|l|l|l|l|l|}
\hline \hline No & Hypothesis & $\begin{array}{l}\text { CR Cut off }> \\
\mathbf{1 . 9 6}\end{array}$ & $\begin{array}{l}\text { P value } \\
\text { Cut off }<0.05\end{array}$ & $\begin{array}{l}\text { Informati } \\
\text { on }\end{array}$ \\
\hline & performance & & & \\
\hline
\end{tabular}

From the 3 the test result for the direct hypotheses show the acceptance because they have a CR value of 1.96 and a $\mathrm{P}$ value $<0.05$ and meet the minimum requirements of accepted hypothesis provisions. In other words, the independent variable, Strategic HRM and knowledge management, have an influence to increase the dependent variable, namely the performance of innovation as long as the independent variable can be improved by the management or management of Zainoel Abidin Regional Public Hospital in Banda Aceh.

\section{Indirect Hypothesis Testing}

The following is an indirect hypothesis test conclusion that is the Effect of Strategic HRM on Innovation Performance of Zainoel Abidin Regional Public Hospital in Banda Aceh through knowledge management. This indirect effect tested usung the resampling or bootsrapping method with a level of confidence of $95 \%$ and a size of resampling of 2000 times.

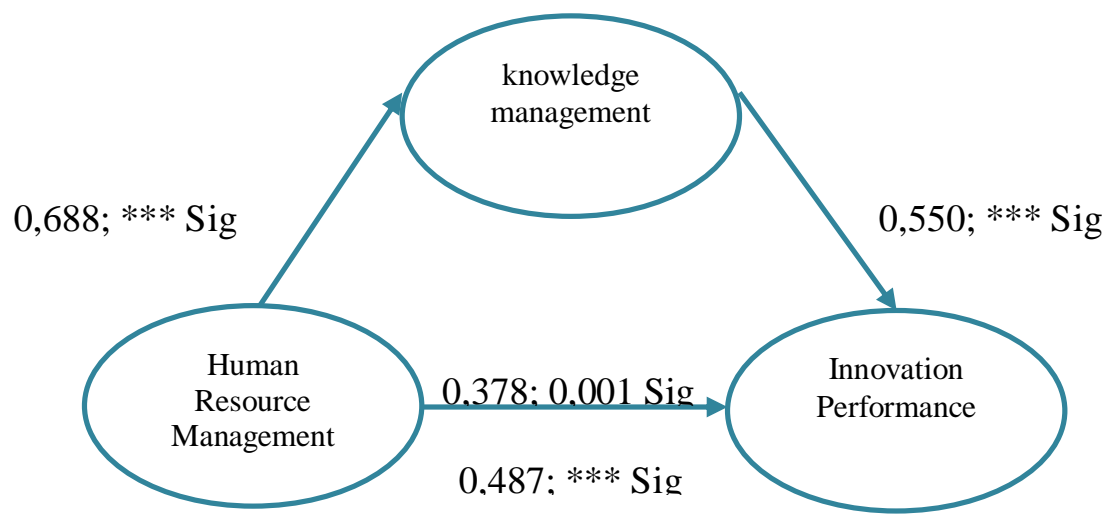

Figure 2. Indirect effect

The conclusion for indirect test result is shown in the table 4 below:

Table 4. Indirect Hypothesis Test Result

\begin{tabular}{|l|l|l|l|l|l|}
\hline No & Indirect Hypothesis & $\begin{array}{l}\mathbf{P} \text { value } \\
\mathbf{< 0 . 0 5}\end{array}$ & Beta & $\begin{array}{l}\text { Informati } \\
\text { on }\end{array}$ & $\begin{array}{l}\text { The Role of } \\
\text { Mediation }\end{array}$ \\
\hline 1 & $\begin{array}{l}\text { The Effect of Strategic HRM } \\
\text { on Innovation Performance } \\
\text { through knowledge } \\
\text { management }\end{array}$ & $0.001(\mathrm{Sig})$ & .378 & Accepted & $\begin{array}{l}\text { Partial } \\
\text { Mediating }\end{array}$ \\
\hline
\end{tabular}




\section{International Journal of Business Management and Economic Review}

Vol. 3, No. 04; 2020

ISSN: 2581-4664

The table 4 can be explained that the effect of Strategic HRM on innovation performance through knowledge management shows the significant result, with $\mathrm{P}$ Value 0.001 , and the coefficient 0.378 . Because of the Strategic HRM affects innovation performance both direct and indirect are significant, then the role of knowledge management in this indirect effect is as a partial mediator.

\section{CONCLUSION}

Some conclusions can be taken from the result and discussion.

1. The influence of Strategic HRM on knowledge management is significant. So the hypothesis 1 is proven and accepted.

2. The Influence of Strategic HRM on Innovation Performance is significant. So the hypothesis 2 is proven and accepted.

3. The influence of Knowledge Management on innovation performance is significant. So the hypothesis 3 is proven and accepted.

4. The indirect effect of the Strategic HRM on the performance of innovation through knowledge management is also proved significant. So hypothesis 4 is proven and accepted.

5. Because the The Influence of Strategic HRM on Innovation Performance both direct and indirect has proven significant, It figures that the role of knowledge management in the indirect effect of the research model is as a partial mediator, meaning that Knowledge management can be a mediator or not in this case.

The suggestions can be provided based on this study are as follows.

1. To support the improvement of innovation performance through knowledge management in this Zainoel Abidin Regional Public Hospital, the most priority variable to improve its ability is the Strategic HRM compared to knowledge management, because of its contribution to the most substantial improvement in Innovation Performance.

2. Increasing the ability of Zainoel Abidin Regional Public Hospital to manage its human resources is the most important factor in improving innovation performance. More concretely that must be done is the existence of knowledge sharing between superiors and subordinates. This means that the attitude of a good superior according to them is a boss who wants to share knowledge for the progress of his subordinates as well.

\section{REFERENCES}

Azhari, Musnadi, S. and Tabrani, M. (2017) 'Pengaruh Manajemen Pengetahuan, Gaya Kepemimpinan Dan Insentif Terhadap Kinerja Pegawai Serta Implikasinya Terhadap Kinerja Organisasi Pada Kantor Pelayanan Pajak Pratama Banda Aceh', Jurnal Manajemen dan Inovasi, 8(3), pp. 37-51.

Bernardin, H. J. and Russell, J. E. A. (2012) Human Resource Management. 6th edn. New York: McGraw-Hill.

Bes, F. T. de and Kotler, P. (2011) Winning at Innovation: The A-to-F Model. London: Palgrave Macmillan. 


\section{International Journal of Business Management and Economic Review}

Vol. 3, No. 04; 2020

ISSN: 2581-4664

Cardeal, N. and Antonio, N. S. (2012) 'Valuable, Rare, Inimitable Resources and Organization (VRIO) Resources or Valuable, Rare, Inimitable Resources (VRI) Capabilities: What Leads to Competitive Advantage?', African Journal of Business Management, 6(37), pp. 10159-10170.

Chen, C.-H. V. and Indartono, S. (2011) 'Study of Commitment Antecedents: The Dynamic Point of View', Journal of Business Ethics, 103(4), pp. 529-541. doi: 10.1007/s10551-0110878-x.

Collins, C. J. and Clark, K. D. (2003) 'Strategic Human Resource Practices, Top Management Team Social Networks, and Firm Performance: The Role of Human Resource Practices in Creating Organizational Competitive Advantage', Academy of Management Journal, 46, pp. 740-751. doi: http://dx.doi.org/10.2307/30040665.

Fachreza, Musnadi, S. and Shabri, M. (2018) 'Pengaruh motivasi kerja, lingkungan kerja, dan budaya organisasi terhadap kinerja karyawan dan dampaknya pada kinerja bank aceh syariah di kota banda aceh', Jurnal Magister Manajemen, 2(1), pp. 115-122.

Ferdinand, A. (2014) Metode Penelitian Manajemen. Edisi 5. Semarang: Universitas Diponegoro.

Hu, M., Horng, J. and Sun, Y. (2009) 'Hospitality teams: knowledge sharing and service innovation performance', Tourism Management, 30(1), pp. 41-50. doi: https://doi.org/10.1016/j.tourman.2008.04.009.

Oke, A., Walumbwa, F. O. and Myers, A. (2012) 'Innovation Strategy, Human Resource Policy, and Firms' Revenue Growth: The Roles of Environmental Uncertainty and Innovation Performance', Decision Sciences, 43(2), pp. 273-302. doi: https://doi.org/10.1111/j.15405915.2011.00350.x.

Palacios, D., Gil, I. and Garrigos, F. (2009) 'The impact of knowledge management on innovation and entrepreneurship in the biotechnology and telecommunications industries', Small Business Economics, 32, pp. 291-301.

Randeree, E. (2006) 'Knowledge management: Securing the future', Journal of Knowledge Management, 10(4), pp. 145-156. doi: 10.1108/13673270610679435.

Rizqina, Z. A., Adam, M. and Chan, S. (2017) 'Pengaruh Budaya Kerja, Kemampuan, dan Komitmen Kerja Terhadap Kepuasan Kerja Pegawai serta Dampaknya Terhadap Kinerja Badan Pengusahaan Kawasan Perdagangan Bebas dan Pelabuhan Bebas Sabang (BPKS)', Jurnal Magister Manajemen, 1(1), pp. 59-69.

Shahnaei, S. and Long, C. S. (2015) 'The Review of Improving Innovation Performance through Human Resource Practices in Organization Performance', Asian Social Science, 11(9), pp. 52-56. doi: http://dx.doi.org/10.5539/ass.v11n9p52.

Sherafati, M., Mohammadi, R. and Bidabad, B. (2014) 'Information Sharing and Advanced Planning in Performance of Saipa Diesel Company Supply Chain: SCOR Approach', Journal of Applied Science and Agriculture, 9(6), pp. 2687-2691. 